\title{
WATER RESOURCES AND GROUNDWATER QUALITY IN NORTH PELOPONNESUS (GREECE)
}

\author{
K.S. VOUDOURIS ${ }^{1 *}$ \\ P. DASKALAKI ${ }^{2}$ \\ A. ANTONAKOS ${ }^{3}$
}

\author{
${ }^{1}$ Lab. of Engineering Geology \& Hydrogeology \\ Dept. of Geology \\ Aristotle University of Thessaloniki. \\ 54124, Thessaloniki, Greece \\ ${ }^{2}$ Cohesion Fund Management and Monitoring Special \\ Service, Ministry of Economy and Finance \\ 10 Nikis Str., Athens, Greece \\ ${ }^{3}$ Lab. of Hydrogeology, University of Patras \\ 261 10, Rio, Patras, Greece
}

Received: 08/11/04

Accepted: 20/03/05 *to whom all correspondence should be addressed Tel: +(30)2310-998041; Fax: +(30)2310-998530 e-mail: kvoudour@geo.auth.gr

\begin{abstract}
Groundwater plays an important role for urban and agricultural water supply in northern part of Peloponnesus. Despite increasing environmental awareness in this area, groundwater is a resource that is being stressed. Groundwater provides about $80 \%$ the total quantity of water supply. Distribution of water resources is nonhomogeneous in this region. In general the eastern part is semiarid, whereas the western part is supplied with abundant water. Surface water potential in North Peloponnesus estimated to be 0.9 $1.2 \times 10^{9} \mathrm{~m}^{3} \mathrm{y}^{-1}$. Overexploitation of groundwater and the extensive agriculture has created environmental problems in some aquifers (sea water intrusion, nitrate pollution). Seawater intrusion occurs in some coastal aquifers, where negative water balance has been established. High percentage of the examined samples exceeded the maximum admissible nitrate concentration of $50 \mathrm{mg} \mathrm{l}^{-1}$, set by EU for drinking water. Groundwater in urban areas has been contaminated to varying degrees. The water quality is classified into $\mathrm{Ca}-\mathrm{HCO}_{3}$ type (fresh water) and $\mathrm{Na}-\mathrm{HCO}_{3}$ or $\mathrm{Na}-\mathrm{Cl}$ type (brackish waters) in the coastal part, due to seawater intrusion. Some recommendations are made in order to safeguard high water quality and to develop new ways of providing water source in the study area. Moreover, an integrated and comprehensive management scheme should be applied, aiming at sustainability of water resources and based on surface water and groundwater exploitation, simultaneously.
\end{abstract}

KEYWORDS: Water resources, groundwater development, groundwater quality, pollution, North Peloponnesus, Greece

\section{INTRODUCTION}

The northern part of the Peloponnesus, in South Greece including the Achaia and Korinthia prefecture, has an extent of $6,000 \mathrm{~km}^{2}$ and a population of about 477,400 (census 2001). Between the 1970's and 2000's the population grew quickly, increasing by $35 \%$ (Table 1). The population density in the coastal areas is 200 persons per $\mathrm{km}^{2}$ and it decreases to 15 persons per $\mathrm{km}^{2}$ in the mountainous area.

The total crops area is $1311 \mathrm{~km}^{2}$ and in a large part $550 \mathrm{~km}^{2}(42 \%)$ irrigated agriculture is practiced during the last decades (Table 2). The land is mainly used for the cultivation of citrus fruits, olives, apricots and vineyards especially in the lowlands. The percentage of 
the irrigation area has increased between 1971-2001 from 25.5 to $41 \%$ (Korinthia) and from 21.8 to $42 \%$ (Achaia). The aforementioned percentage is one of the higher in Greece.

Table 1. Population in the studied area

\begin{tabular}{|l|c|c|c|c|c|}
\hline Year/Prefecture & $\mathbf{1 9 6 1}$ & $\mathbf{1 9 7 1}$ & $\mathbf{1 9 8 1}$ & $\mathbf{1 9 9 1}$ & $\mathbf{2 0 0 1}$ \\
\hline Achaia & 240,201 & 240,854 & 275,193 & 300,078 & 322,789 \\
\hline Korinthia & 112,505 & 113,115 & 123,042 & 141,823 & 154,624 \\
\hline Total & 352,706 & 353,969 & 398,235 & 441,901 & 477,413 \\
\hline
\end{tabular}

Table 2. Total crops and irrigated areas in stremmas

\begin{tabular}{|l|l|l|}
\hline Year & $\begin{array}{l}\text { Korinthia prefecture } \\
\text { Total crops-irrigated areas }\end{array}$ & $\begin{array}{l}\text { Achaia prefecture } \\
\text { Total crops-irrigated areas }\end{array}$ \\
\hline 1971 & $583,990-149,085(25.5 \%)$ & $707,027-154,475(21.8 \%)$ \\
\hline 1991 & $544,789-167,071(30.7 \%)$ & $615,428-188,260(30.6 \%)$ \\
\hline 1998 & $622,679-253,807(40.8 \%)$ & $709,242-285,412(40.2 \%)$ \\
\hline 2001 & $625,906-256,485(41.0 \%)$ & $685,581-292,748(42.0 \%)$ \\
\hline
\end{tabular}

The coastal part of the study area can be characterized as an agrotourism center in the sense of an agriculturally streamlined and tourism developed area that bounds a wellstructured and densely populated urban environment (Kassimis, 1998). Water scarcity is recognized as an increasing problem and has became a vital problem for socioeconomic development of coastal part of the studied area. Water demands have continuously increased over the last 25 years in response to population growth due to rapid urbanization and agricultural activities.

The water supply is mainly covered by groundwater abstracted from the alluvial coastal aquifers via numerous wells and boreholes. The number of wells and boreholes has reached 8,000 in Korinthia prefecture (Voudouris, 1995, Panagopoulos et al., 2002). As a result a decline of ground water levels has been observed, since 1980's due to overexploitation of agricultural and municipal water intakes in coastal part of the study area combined with prolonged drought periods (Lambrakis et al., 1997). Furthermore a negative water balance is established in the coastal aquifer systems. In these systems seawater intrusion is recorded due to over-pumping combined with prolonged dry periods. An increase in the dissolved components in the groundwater, especially chloride and sodium, has been observed in many boreholes drilled into aquifers, along the coastline of the study area (Daskalaki et al., 1998).

Nitrate pollution is the second major source of groundwater degradation in the study area. Nitrate is a common contaminant identified in groundwater of the study area, due to the irrational application of fertilizers. The common fertilizer applied throughout the irrigation area is $\left(\mathrm{NH}_{4}\right)_{2} \mathrm{SO}_{4}$, phosphate and potash. Under a nitrification process in the presence of oxygen, ammonium is transformed into nitrate (Freeze and Cherry, 1979). The high levels of nitrate are probably the result of the lack of sewage systems in some urban areas. The main pollution source of surface water results from uncontrolled direct disposal of raw olive mill waste effluent into the torrents and rivers (Voudouris et al., 2000).

The aim of this study is to describe the hydrogeological regime in Northern Peloponnesus, the existing water resources management policy and the implications it has on groundwater quality. The study was carried out on the basis of an attempt to establish a policy for the sustainable development and management of water resources.

\section{THE STUDY AREA}

\subsection{Morphology}

The study area is surrounded by sea in northern part and can be considered as a mountainous area (mountains: Helmos 2355 m, Killini 2376 m, Erimanthos 2224 m, Panachaiko $1926 \mathrm{~m})$. 
A number of torrents/rivers run across the studied region (Figure 1) namely: Piros, Glafkos, Charadros, Volineos, Finikas, Selinountas, Vouraikos, Meganitis, Kerinitis, Krathis, Fonisa, Sithas, Asopos, Zapantis and Xirias. All of them discharge into Korinthiakos Gulf except Piros, Glafkos and Charadros, which discharge into the Patraikos Gulf. The mountainous areas are the sources of the surface water runoff and the lowlands are its discharge areas. Thus, the torrents/rivers play a mayor role to the recharge of the coastal aquifer systems.

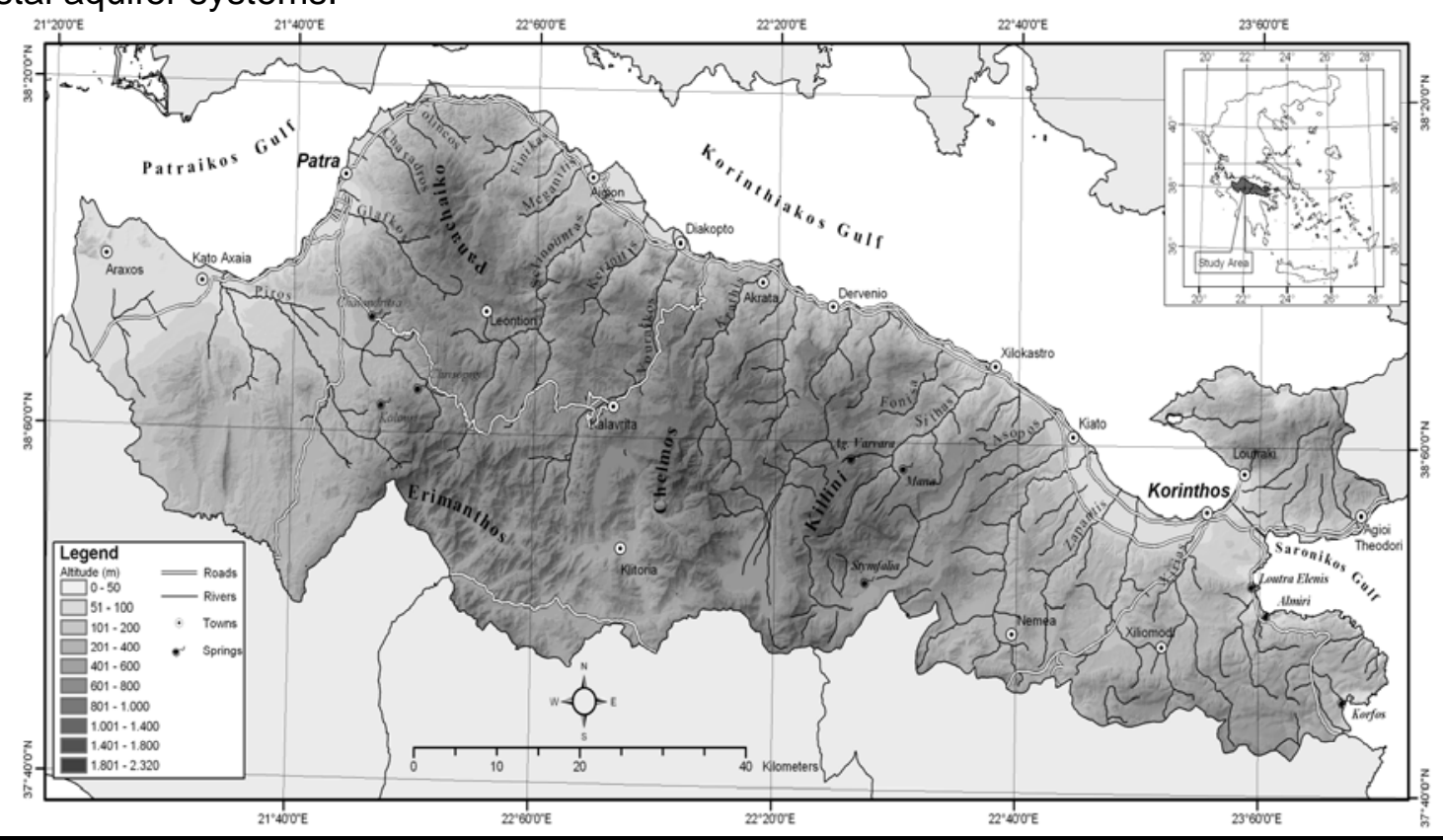

Figure 1. Location map of the study area, showing geographical features

The Asopos river flow constitutes the basic source of irrigation water in the eastern part of the study area and is being managed via a diversion dam followed by a dense network of lined canals. The mean annual runoff in each torrent/river basin, as suggested by Koukis et al. (1996) and Voudouris et al. (1997) is presented in Table 3. Hence, is a very large surface water potential in North Peloponnesus estimated to be $0.9-1.2 \times 10^{9} \mathrm{~m}^{3} \mathrm{y}^{-1}$.

Table 3. Mean annual runoff of torrent/river basins in North Peloponnesus

\begin{tabular}{|c|c|c|}
\hline Torrent/River & $\begin{array}{c}\text { Catchment surface area } \\
\left(\mathrm{km}^{2}\right)\end{array}$ & $\begin{array}{c}\text { Mean annual flow } \\
\left(\times 10^{6} \mathrm{~m}^{3}\right)\end{array}$ \\
\hline Piros & 506 & 115.6 \\
\hline Glafkos & 118.1 & 32.1 \\
\hline Charadros & 23.8 & 7.4 \\
\hline Volineos & 26.4 & 7.2 \\
\hline Finikas & 100.6 & 25.7 \\
\hline Selinountas & 285 & 73.0 \\
\hline Vouraikos & 183 & 116.0 \\
\hline Meganitis & 60.1 & 26.0 \\
\hline Kerinitis & 80 & 35.0 \\
\hline Krathis & 166 & 68.0 \\
\hline Fonisa & 54 & 27.0 \\
\hline Sithas & 180 & 18.4 \\
\hline Asopos & 284 & 50.0 \\
\hline Zapantis & 140 & 7.5 \\
\hline Xirias & 174 & 3.8 \\
\hline
\end{tabular}


Table 4. Simplified geological sequence in north Peloponnesus

\begin{tabular}{lcc}
\hline Geological Period & Location & Description \\
\hline Quaternary & $\begin{array}{c}\text { Northern part } \\
\text { (coastal areas or } \\
\text { inland basins) }\end{array}$ & $\begin{array}{c}\text { Unconsolidated sediments } \\
\text { sands, pebbles, breccias and } \\
\text { fine clay to silty sand deposits }\end{array}$ \\
Plio-Pleistocene & Semi-mountainous area & $\begin{array}{c}\text { Coarse grained (conglomerates) } \\
\text { Fine grained (marls) }\end{array}$ \\
Alpine formations & $\begin{array}{c}\text { Southern part } \\
\text { mountainous area }\end{array}$ & $\begin{array}{c}\text { Flysch, limestones, dolomites } \\
\text { semi-metamorphic formations }\end{array}$
\end{tabular}

In the Stimfalia basin (Korinthia prefecture) there is the homonymous shallow lake, which is one of the Greece's mountain lakes, covering an area of 750 hectares. The lake is recharged from the karstic springs and a considerable fraction of surface runoff is augmenting lowland irrigation networks via Asopos river (Voudouris et al., 2002b).

\subsection{Climate}

The climate of North Peloponnesus is Mediterranean of hot, dry summers and mild, wet winters. In western part is wet and in eastern part dry. There is a systematic variation in the distribution of rainfall in the area due to oreographic influence of the mountains. Based on data from 37 raingage stations, the precipitation is correlated strongest with the altitude and increases by $40 \mathrm{~mm}$ per $100 \mathrm{~m}$. The 30-year average of rainfall at sea level is $710 \mathrm{~mm}$ in western part (Patras raingage) and $400 \mathrm{~mm}$ in eastern part (Korinthos raingage). The results from regression analysis (Voudouris, 1999) show a decrease of $3.26 \mathrm{~mm} \mathrm{~km} \mathrm{~m}^{-1}$ of movement Eastward and a decrease of $1.2 \mathrm{~mm} \mathrm{~km}^{-1}$ for movement Northward. Rainfall is seasonal occurring in the wet period October-April (83\% of the annual precipitation).

Average annual temperature range from $18{ }^{\circ} \mathrm{C}$ at mean sea level and decreases by 0.59 ${ }^{\circ} \mathrm{C}$ per $100 \mathrm{~m}$ of ground elevation; daytime summer temperatures are above $30{ }^{\circ} \mathrm{C}$ in the coastal areas (Voudouris et al, 2002a). Annual potential evapotranspiration exceeds rainfall at all the stations. The coefficient of real evapotranspiration ranges from $78 \%$ of the annual precipitation (in lowland) to $45 \%$ (in highland). Direct recharge of precipitation to groundwater takes place in wet period (November-March). The percentage of rainfall which infiltrates through the soil has been estimated to be $50 \%$ of the annual precipitation in the carbonate areas, $20 \%$ in the alluvial areas and $3-5 \%$ in low permeability areas (flysch, phyllites, fine grained neogene deposits).

An increased number of droughts (1977, 1989-91, 2000), as well floods (1997) have occurred during the last three decades (Voudouris et al, 2002a). Lambrakis et al. (1997) and Voudouris et al. (2002a) concluded that the annual precipitation depth in raingage stations from the study area, displays a decreasing trend over the last 50 years.

\subsection{Geology}

According to Voudouris (1995), Nikolaou et al. (1997), the following geological formations can be identified (Table 3):

- Quaternary deposits consisting of alternations of sands and fine coarse or mixed facies. The plain, north of the national highway Patras-Korinthos, is formed of recent unconsolidated material consisting of sands, pebbles, breccias and fine clay to silty sand deposits. Lateral continuity of afore described deposits is disrupted by recent and older fluvio-torrential deposits originating from the streams-rivers that flow across the studied region, as illustrated in the geological map of Figure 2. The thickness of the plain's deposits varies from $30 \mathrm{~m}$ to $70 \mathrm{~m}$, whilst along the fluvio-torrential deposits of the rivers it 
exceeds $100 \mathrm{~m}$. As a result of their origin the deposits are characterized by high degree of heterogeneity and anisotropy.

- Plio-Pleistocene deposits. They form the semi-mountainous region covering a large area South of the national highway Korinthos-Patras and they consist of two formations; a) the coarse grained of alpine origin conglomerates cemented by calcareous clay, b) the fine grained, of marl, clay and sand, characterized by heterogeneity in the horizontal and vertical evolution. The Lower Pleistocene uplift and subsidence movements have contributed to the formation of the Tyrrhenian marine terraces in eastern part. A number of springs develop along the unconformity between the conglomerates and the fine grained formation. The Upper Pliocene conglomerates in Nemea and Stimfalis area have a thickness of over $300 \mathrm{~m}$, consisting of pebbles and cobbles cemented together with clay and fine sand.

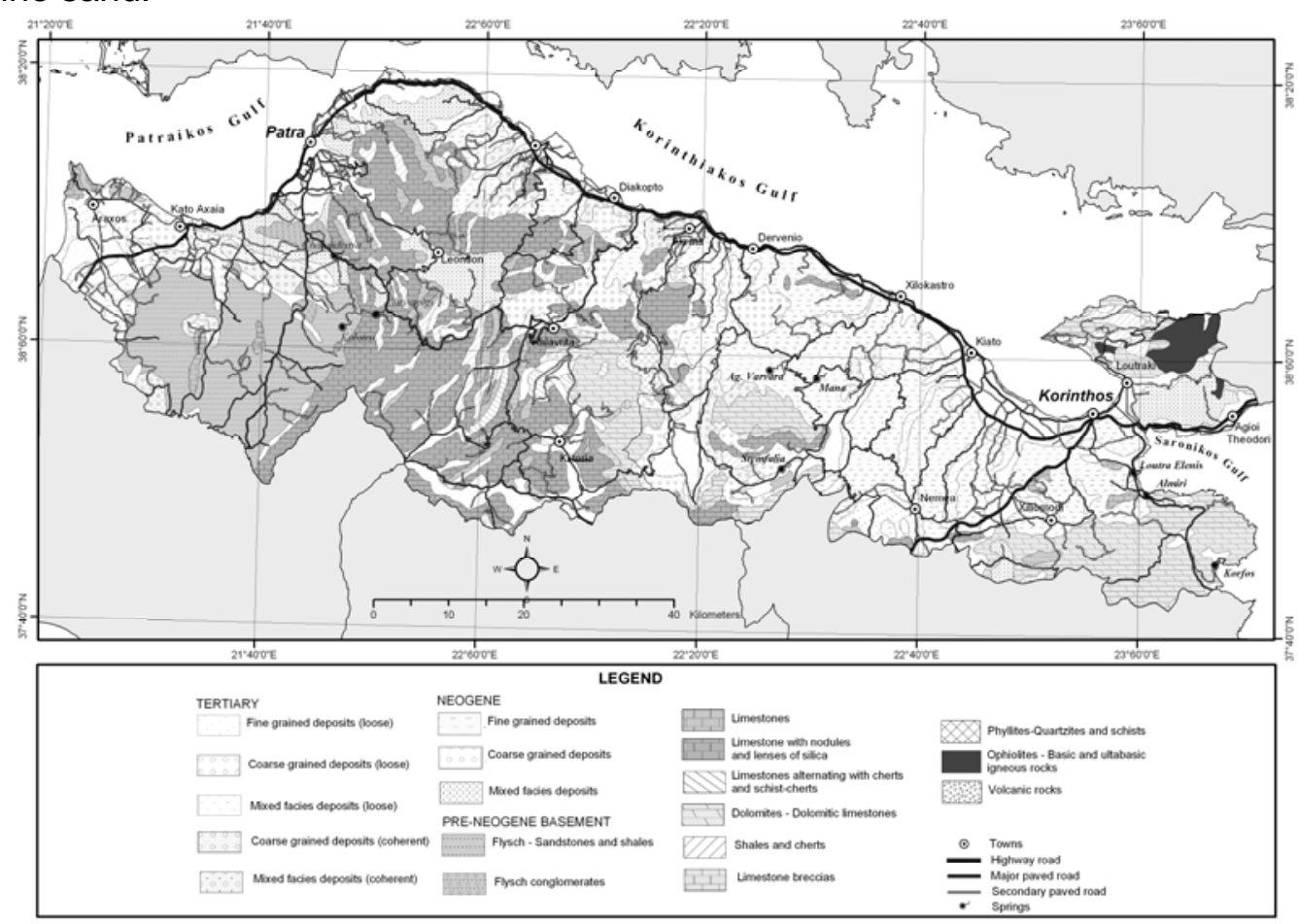

Figure 2. Geological map of the North Peloponnesus

- The Alpine formations which comprise part of the following Hellinides zones; a) Flysch and limestones of the Ionian zone, b) Flysch and limestones of the Tripolis zone, c) Limestones with chert intercalations and flysch of the Olonos-Pindos zone, d) Limestone and dolomite of Pelagonic zone, e) Semi-metamorphic formations (phyllites, siltstones, sandstones and limestones), f) volcanic rocks, g) ophiolite complex and h) palaeozoic limestones of very small extension.

The limestones of the Pindos and Tripolis zone are characterized by the presence of a joint system, which favors infiltration of rainfall and karstification.

\subsection{Aquifers}

The complicated geological structure of the study area results in complex hydrogeological conditions. Distribution of groundwater is nonhomogeneous in the region. The main aquifers in the area are of three types:

1. Aquifers of alluvial deposits

Alluvial aquifers are hosted in coastal areas and inland basins, supplying large quantities of water. The groundwater in the alluvium consists of phreatic and confined groundwater. The water table elevation is highest in April and lowest in October. Groundwater use on the coastal part exceeds natural recharge in dry period, and water levels decline to an extent that depends on the difference between abstraction and recharge. The hydrograph 
shows various water level fluctuations and that the water level declined during the dry periods (Fig. 3). In recent years many borehole fields have been established in the coastal area. Overexploitation causes a negative water balance in the many coastal aquifer systems, triggering saline water intrusion, which has negative consequences for the socioeconomic development of the area (Stamatis and Voudouris, 2003).

The beginning of the decline of the groundwater level in the coastal alluvial aquifer of Glafkos basin coincides with the increase of groundwater extraction by the Patras municipality (1984-1986) and the beginning of the drought periods (1989-1991). An increase of groundwater level was recorded in the aforementioned aquifer during the period 1994-2001 (Fig. 4). In this period the total amount of groundwater extracted for domestic and industrial purposes decreased, due to quality deterioration and deindustrialization, respectively (Mandilaras et al., 1999).

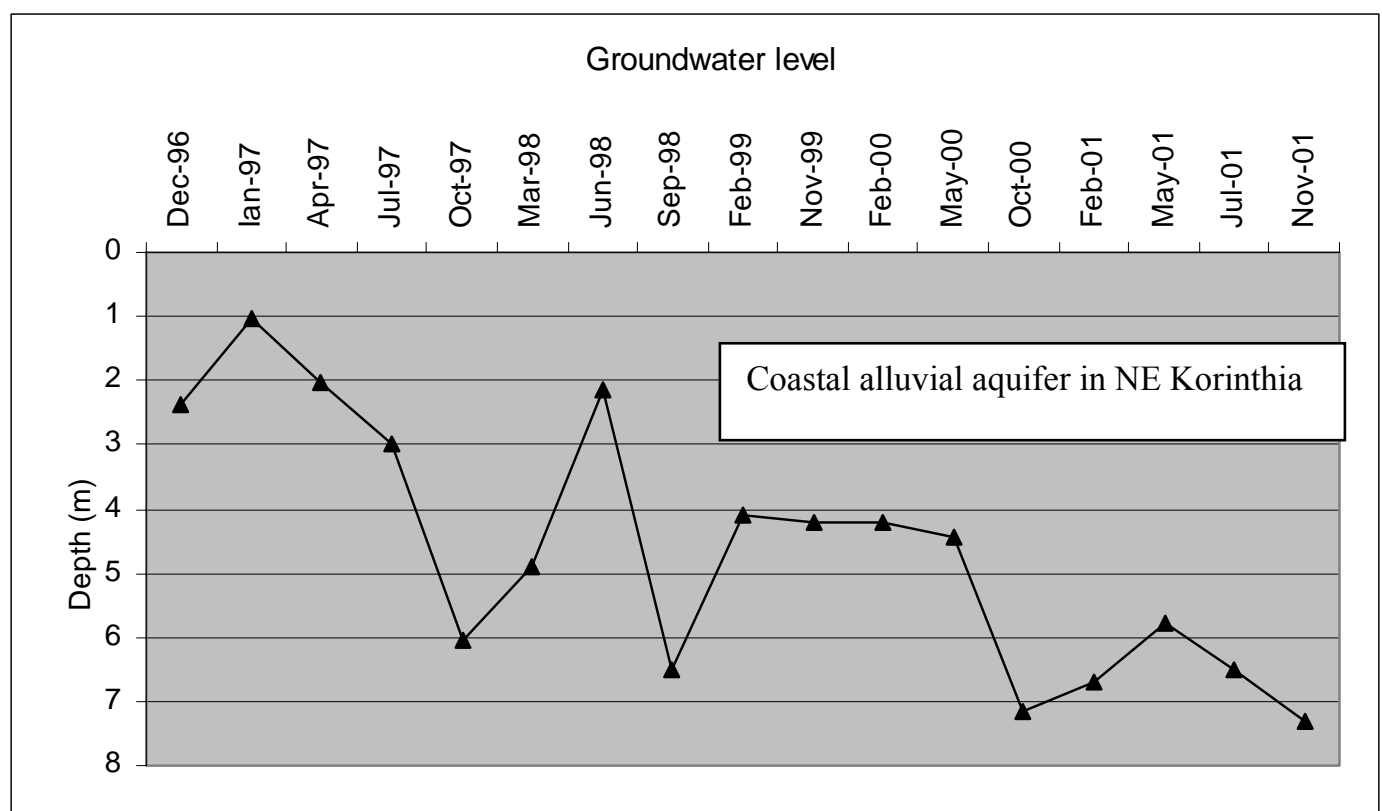

Figure 3. Hydrograph of groundwater table fluctuations (meters from the ground surface) in coastal aquifer system of Asopos basin

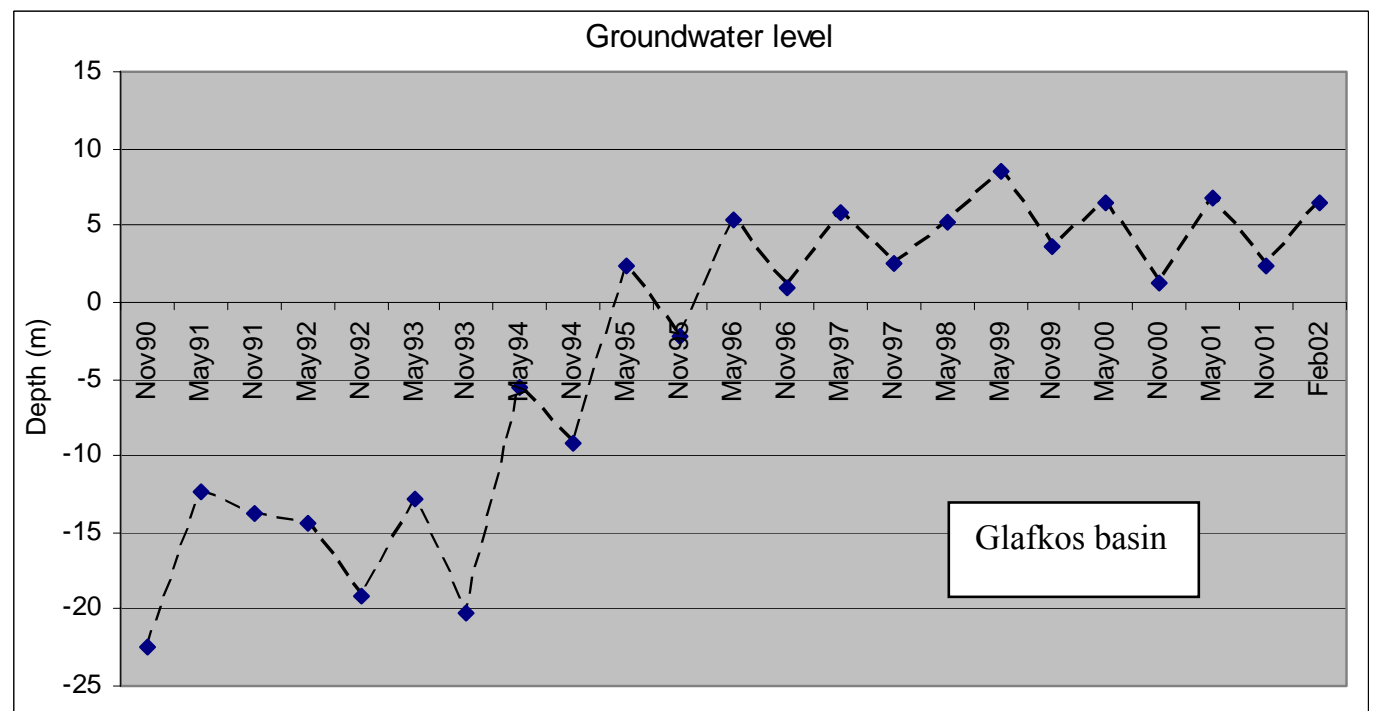

Figure 4. Hydrograph of groundwater table fluctuations (meters from the ground surface) in the coastal alluvial aquifer of Glafkos basin 
Groundwater flow approximately follows the surface drainage pattern. Overexploitation has caused a decline of groundwater levels in aquifer systems and changes in the direction and velocity of groundwater flow. The average hydraulic conductivity is $\mathrm{k}=2 \times 10^{-4}$ $\mathrm{m} \mathrm{s}^{-1}$ as deduced from the conducted pumping test analyses (Voudouris, 1995, Koumantakis et al., 1999). The yield of boreholes ranges from $10-80 \mathrm{~m}^{3} \mathrm{~h}^{-1}$.

Groundwater recharge of the aquifer mainly takes place by seepage through the riverbed and direct infiltration during rainfall. Urbanization in the coastal part has resulted in the construction of buildings and an increase in paved areas causing a reduction in direct groundwater recharge and the generation of additional surface runoff.

2. Aquifers of Plio-Pleistocene deposits

These aquifers are hosted in the terrestrial facies of neogene deposits (conglomerates, sandstones), forming a multiple aquifer system, which is at least $200 \mathrm{~m}$ thick. For example, the aquifer of Patras industrial area is the main aquifer for its groundwater resources with annual abstraction about of $2 \times 10^{6} \mathrm{~m}^{3}$ (Voudouris et al., 2002c). The age of groundwater from aforementioned aquifer, based on tritium and radio carbon dating ranges from 40 to 600 years old. (Voudouris, 1995).

Transmissivity $(T)$ and Storage coefficient $(S)$ values vary between $T=55-110 \mathrm{~m}^{2} \mathrm{~d}^{-1}$ and $S=8 \times 10^{-4}-2 \times 10^{-3}$, respectively. The aquifer of Pleistocene deposits (Tyrrhenian) in the eastern part has a low potential, which is attributed to the heterogeneity of its clastic material, its limited thickness and its fragmentation as a result of tectonic faulting (Stamatis and Voudouris, 2003). Analysis of pumping test data from boreholes drilled in Upper Pliocene conglomerates showed double porosity features and Transmissivity values between $45-62 \mathrm{~m}^{2} \mathrm{~d}^{-1}$.

3. Karst aquifers

The karst aquifers are hosted in carbonate rocks which show a high water permeability due to its well developed wide jointing and its karstification. The yield of boreholes ranges from 30 to $250 \mathrm{~m}^{3} \mathrm{~h}^{-1}$ and Transmissivity varies between 50 and $950 \mathrm{~m}^{2} \mathrm{~d}^{-1}$ (Voudouris, 1995). Karst aquifer systems often discharge groundwater through large springs, e.g. Stimafalia, Mana, Agia Varvara, Chalandritsa, Skiadas, Kalousi, Chrisopigi etc (Skayias 1978). The location of springs are shown in Figure 1.

Seawater intrusion phenomena in karst aquifers have recorded in recent years, due to intensive exploitation (Kamari, Spathovouni). In the eastern part of the study area the karst aquifer is in direct hydraulic communication with the sea, contributing to seawater intrusion. A common feature in the karst system surrounding this area are solutions channels, which discharge water as submarine springs (Loutra Elenis, Almiros, Korfos).

\section{GROUNDWATER QUALITY}

Groundwaters typically have a large range in chemical composition attributing to differences in: interaction with lithosphere, atmosphere and biosphere, recharge rate, anthropogenic activities, temperature and pressure.

In order, to determine the groundwater quality, the chemical analyses results of 460 samples were used. The majority of the analyses were carried out in the laboratory of Hydrogeology of the Patras University. The water quality data from other investigations (Agriculture ministry, General Chemical laboratory of the state, Institute of Geology and Mineral Exploration) are used in the current study for comparative purposes (Daskalaki, 2002). The measured chemical parameters of 50 representative groundwater samples are presented in Table 5 and the sampling location in Fig. 6.

The $\mathrm{pH}$ values are greater than 7 , indicating the slightly alkaline character of groundwater. Electrical conductivity is low in freshwater recharge area and progressively increases towards the coastline (Fig. 5). In recharge areas the prevailing ions are $\mathrm{Ca}^{2+}$ and $\mathrm{HCO}_{3}$. Moving seawards $\mathrm{Na}^{+}, \mathrm{Cl}^{-}, \mathrm{K}^{+}$are the prevailing ions. The lowest concentration of sulfate $\left(\mathrm{SO}_{4}{ }^{2-}<30 \mathrm{mg} \mathrm{l}^{-1}\right)$ occurs in groundwater from mountainous area. 


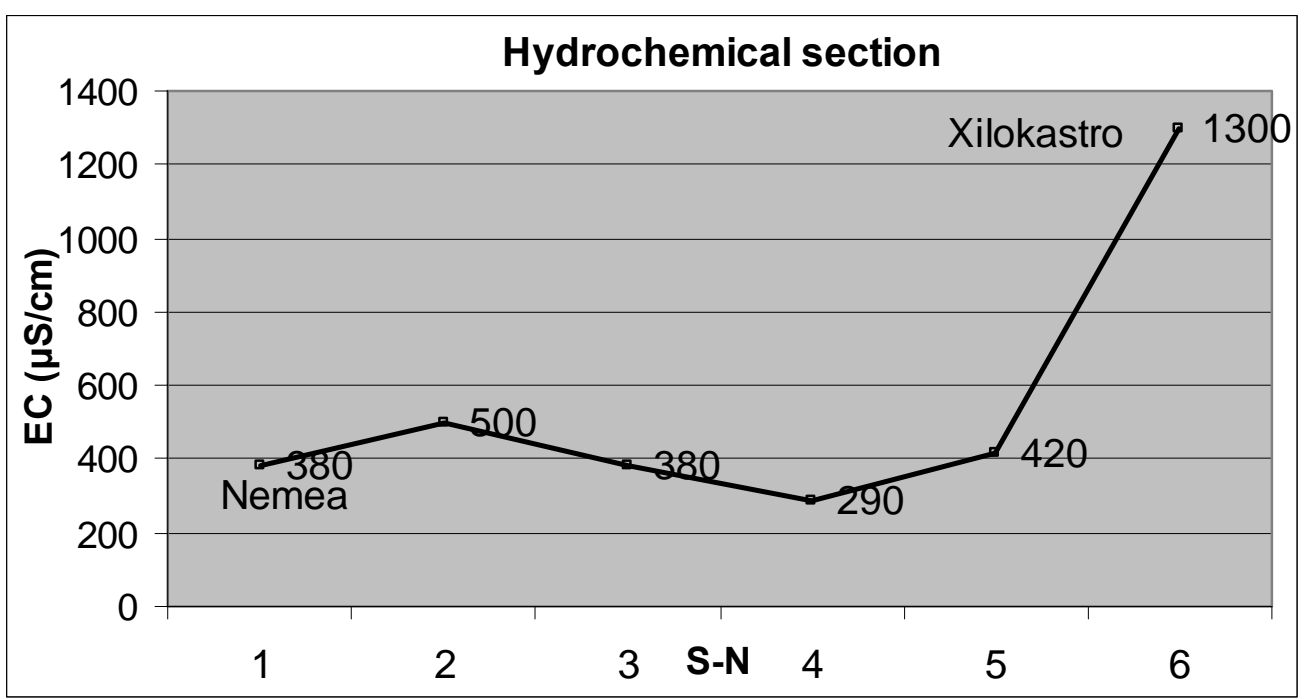

Figure 5. Hydrochemical section from south to north in Asopos basin

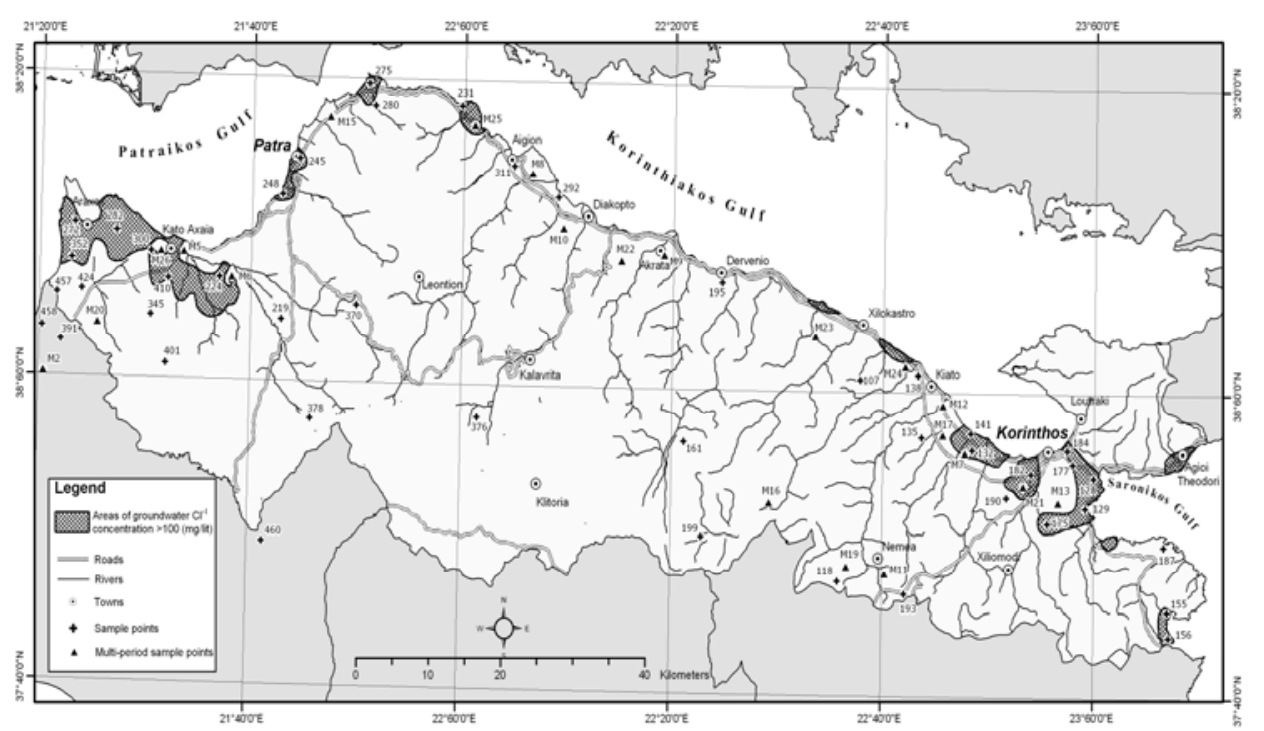

Figure 6. Areas affected by seawater intrusion $\left(\mathrm{Cl}^{-}\right.$concentration $\left.>100 \mathrm{mg} \mathrm{l}^{-1}\right)$

The waters are of various hydrochemical types: $\mathrm{Ca}-\mathrm{HCO}_{3}$ (freshwater of recent infiltration from mountainous area suitable for drinking purpose), $\mathrm{Na}-\mathrm{HCO}_{3}$ (this type indicates ionexchange phenomena and characterizes a transition zone) and $\mathrm{Na}-\mathrm{Cl}$ (typical brackish water from coastal aquifers affected by seawater intrusion, in which the ions $\mathrm{Na}^{+}$and $\mathrm{Cl}^{-}$ predominate). The $\mathrm{Mg}-\mathrm{HCO}_{3}$ type of groundwater is recorder in Loutraki alluvial aquifer.

The shallow alluvial aquifers are under risk of anthropogenic pollution (nitrate pollution). Groundwater in urban areas has been contaminated to varying degrees. Central municipal sewage-treatment systems exist in the big cities (Patras, Aigio, Korinthos, Kiato, Xilokastro). In other places municipal waste water is generally collected into uncontrolled septic tanks, contributing to groundwater contamination. In mountainous area, the municipalities use the main fault zones and karstic features as sites for their solid waste and wastewater disposals. Surface water quality deterioration is also apparent and is mainly attributed to the uncontrollable discharge of untreated olive oil mill effluent.

\subsection{Seawater intrusion}

The saltwater intrusion is caused by over-pumping, water abstraction from great depths, and lack of reliable water resources management. The overexploitation of coastal aquifers always produces a lowering to the water table levels. When the extracted volumes are 
greater than the recharge, even on local base, a salinisation process begins in the aquifer as the seawater flows upon the land. The seawater intrusion has been favored by some preferential paths, depending upon the hydrogeological conditions of each area.

Based on chemical analyses, seawater intrusion takes place in areas (Fig. 6) near utilized groundwater sources (borehole fields). In the western part seawater intrusion phenomena are recorded between Metochi and Sagaiika, Lakopetra, Araxos and Glafkos basin (Voudouris et al., 2004a). Based on piezometric measurements, the seawater intrusion zone extend up to $1 \mathrm{~km}$ from the shore in the coastal alluvial aquifer of Glafkos basin (Mandilaras et al., 1999).

In the eastern part high chloride concentrations are depicted in the coastal region between Lecheo and Vraxati, Melisi and Kamari and Kexrees. According to Stamatis and Voudouris (2003), a comparison of $\mathrm{Cl}^{-}$concentration distribution between 1968 and 1998 indicates that, seawater intrusion expanded in eastern Korinthos area, as a result of overexploitation of the aquifer. A gradual decline of chloride concentrations from coastline to recharge areas is observed (Panagopoulos et al., 2001).

\subsection{Nitrate contamination}

Nitrate is the most abundant nutrient in groundwater. As shown in Table 5, nitrate concentrations range between $0-186 \mathrm{mg} \mathrm{l}^{-1}$; the mean nitrate value is $21.7 \mathrm{mg} \mathrm{l}^{-1}$ and the max admissible concentration of $50 \mathrm{mg} \mathrm{l}^{-1}$ set by EU (1998) for drinking water, is exceeded especially in the eastern part of study area (Voudouris et al., 2004b). Possible negative health effects of high nitrate concentrations are methemoglobulinemia, especially for infants. Nitrates are noticeable throughout the entire region rendering most of groundwater improper for human consumption.

From Fig. 7 , it can be seen that sites with high concentration of nitrate $\left(>50 \mathrm{mg} \mathrm{l}^{-1}\right)$ occur in: a zone extending near to Lapas, Kato Achaia (western part of the study area) and Zevgolatio, Examilia, Ancient Korinthos, Agios Basilios (eastern part of the study area).

The previous mentioned areas are characterized by intense agricultural activity and the high nitrate concentrations in groundwater are related to over-fertilization. Also, localized high phosphate concentrations $\left(\mathrm{PO}_{4}{ }^{3-}>0.3 \mathrm{mg} \mathrm{l}^{-1}\right)$ can be attributed to the use of fertilizers.

Nitrate concentrations are higher in the dry season and progressively reduce in the wet season. Based on the average hydraulic parameters of the coastal alluvial aquifer systems of Korinthia prefecture, it is calculated that a period of 16 years is required to restore groundwater quality to a background level of $15 \mathrm{mg} \mathrm{l}^{-1}$, provided that complete cessation of fertilization is enforced (Voudouris et al., 2004b).

High nitrite $\left(\mathrm{NO}_{2}{ }^{-}\right)$concentrations and $\mathrm{NH}_{4}{ }^{+}$are recorded in urban areas and can be associated with the human activities.

\subsection{The change of the groundwater quality through time}

Table 6 presents the chloride and nitrate concentrations, based on chemical analyses results of 26 representative groundwater samples, during the years 1997 and 1999. Figure 8 shows the chloride concentration changes of selected groundwater samples in this period. As can be seen, $\mathrm{Cl}^{-}$concentration increases in some coastal aquifers, during the period 1997-1999 (Daskalaki, 2002). The concentration of chloride in groundwater has increased to more than $6500 \mathrm{mg} \mathrm{l}^{-1}$ in some boreholes at the end of the prolonged drought periods (Fig. 9).

Figure 10 shows the nitrate variation of selected groundwater samples during the years 1997 and 1999. In 1999, the conditions remain the same in most sites. A comparison of nitrate concentration from phreatic aquifer in Korinthos area, between the periods 1968 and 1998 indicates that, the deterioration of groundwater quality is attributed to nitrate pollution, originating from the excessive use of fertilizers (Stamatis and Voudouris, 2003) 
Table 5. Chemical composition of 50 representative groundwater samples; concentrations in $\mathrm{mgl}^{-1}$, Electrical Conductivity in $\mu \mathrm{S} / \mathrm{cm}$ (sampling location as seen in Fig. 6)

\begin{tabular}{|c|c|c|c|c|c|c|c|c|c|c|}
\hline No & $\mathrm{pH}$ & EC & $\mathrm{Ca}^{2+}$ & $\mathrm{Mg}^{2+}$ & $\mathrm{Na}^{+}$ & $\mathrm{K}^{+}$ & $\mathrm{Cl}^{-}$ & $\mathrm{NO}_{3}{ }^{-}$ & $\mathrm{SO}_{4}{ }^{2-}$ & $\mathrm{HCO}_{3}^{-}$ \\
\hline 107 & 7 & 1060 & 155 & 39 & 33 & 2 & 33 & 68 & 122 & 430 \\
\hline 118 & 7 & 250 & 97 & 3 & 5.1 & 2.2 & 17.7 & 0 & 12 & 110 \\
\hline 128 & 7 & 1050 & 59.8 & 55.9 & 9.2 & 1.2 & 134 & 25 & 88 & 325 \\
\hline 129 & 7.6 & 850 & 333 & 423 & 3450 & 223 & 6384 & 3.7 & 901 & 560 \\
\hline 132 & 7.1 & 780 & 40 & 68 & 30 & 2.8 & 113 & 30.5 & 156 & 450 \\
\hline 135 & 7.05 & 1210 & 48 & 52 & 167 & 4.5 & 99 & 57 & 28 & 256 \\
\hline 138 & 6.9 & 1385 & 198 & 69 & 78 & 4 & 92 & 89 & 212 & 498 \\
\hline 141 & 7 & 1200 & 139.5 & 57.8 & 12.5 & 2.3 & 109.9 & 2 & 115 & 450 \\
\hline 155 & 7.6 & 550 & 353 & 627 & 5336 & 313 & 9752 & 4.3 & 1385 & 306 \\
\hline 156 & 7.4 & 510 & 361 & 856 & 6900 & 340 & 12695 & 4.3 & 1807 & 259 \\
\hline 161 & 7.7 & 505 & 67 & 7 & 2 & 1 & 5 & 2.5 & 6 & 226 \\
\hline 175 & 7.45 & 760 & 107 & 149 & 247 & 50 & 339 & 17.6 & 365 & 664 \\
\hline 177 & 7.85 & 780 & 38 & 81 & 90 & 0.7 & 172 & 44 & 56 & 351 \\
\hline 182 & 7.8 & 1950 & 125 & 105 & 173 & 9 & 295 & 126 & 185 & 730 \\
\hline 184 & 7.38 & 840 & 174 & 521 & 474 & 62 & 2329 & 19.8 & 24 & 347 \\
\hline 187 & 7.3 & 690 & 99.4 & 11.7 & 9.2 & 8.6 & 17.7 & 17.4 & 25.9 & 316 \\
\hline 190 & 7.4 & 820 & 89.8 & 4.4 & 9.66 & 0.39 & 21.3 & 3.7 & 3.8 & 274.5 \\
\hline 193 & 7 & 600 & 99.6 & 21.5 & 10 & 0.2 & 28.3 & 9 & 47 & 190 \\
\hline 195 & 7 & 380 & 63.8 & 26.7 & 3 & 0.4 & 14 & 5 & 35 & 332 \\
\hline 199 & 7 & 420 & 75.7 & 7 & 3 & 0.4 & 21.2 & 10 & 6 & 310 \\
\hline 219 & 7.78 & 900 & 16 & 5.52 & 185.5 & 0.9 & 114 & 2.3 & 2 & 386.5 \\
\hline 224 & 7.11 & 1350 & 193.6 & 16.8 & 82.4 & 3.8 & 131 & 1.7 & 190 & 450.2 \\
\hline 231 & 7.16 & 325 & 95.2 & 4.6 & 7 & 1.1 & 9 & 2.6 & 34 & 261.1 \\
\hline 245 & 7.38 & 1050 & 106.8 & 1.2 & 115.3 & 3.7 & 207 & 2.6 & 48 & 262.3 \\
\hline 248 & 7.98 & 380 & 119.2 & 2.4 & 11 & 1.5 & 14 & 14.7 & 19 & 335.5 \\
\hline 272 & 7.5 & 1330 & 174.3 & 34 & 59.8 & 31.3 & 106.3 & 0 & 408.3 & 158.6 \\
\hline 275 & 7.6 & 815 & 104.2 & 21.9 & 34.5 & 6.2 & 95.7 & 0 & 9.61 & 341.7 \\
\hline 280 & 7.4 & 1700 & 208.4 & 47.4 & 87.4 & 43. & 393.5 & 186 & 105.7 & 292.9 \\
\hline 282 & 7.3 & 1650 & 350 & 51.1 & 68.9 & 43.2 & 233.9 & 31 & 240 & 286.8 \\
\hline 292 & 7.8 & 400 & 40.1 & 24.3 & 2.76 & 3.1 & 3.5 & 11 & 4.8 & 244.0 \\
\hline 300 & 7.6 & 1950 & 160.3 & 25.5 & 133.3 & 82.4 & 386.4 & 4.5 & 120.1 & 2806.6 \\
\hline 311 & 7.4 & 440 & 80.2 & 3.6 & 4.6 & 3.9 & 7.1 & 16 & 19.2 & 244.1 \\
\hline 345 & 7.4 & 1160 & 120.2 & 38.9 & 45.9 & 19.5 & 141.8 & 30 & 134.5 & 299 \\
\hline 352 & 7.5 & 1820 & 60.1 & 48.6 & 147.1 & 156.4 & 283.6 & 22 & 19.2 & 549.1 \\
\hline 370 & 7.87 & 340 & 85.8 & 1.2 & 6.8 & 0.7 & 3.9 & 1.55 & 0.05 & 251.6 \\
\hline 376 & 7.85 & 239 & 65.93 & 3.0 & 2.3 & 0.9 & 8.8 & 1.3 & 9.6 & 215.4 \\
\hline 378 & 8.04 & 274 & 70.1 & 2.4 & 6 & 0.4 & 12 & 1.3 & 2.0 & 217.2 \\
\hline 383 & 7.27 & 940 & 136.3 & 17.0 & 46 & 19.5 & 60.3 & 5 & 91.3 & 402.7 \\
\hline 385 & 7.75 & 680 & 120.2 & 4.9 & 29.9 & 27.4 & 39 & 25 & 57.6 & 329.5 \\
\hline 388 & 7.37 & 550 & 92.2 & 4.8 & 6.9 & 35.2 & 7.1 & 3.3 & 43.2 & 256.2 \\
\hline 389 & 7 & 1090 & 240 & 19.5 & 28.9 & 27.3 & 38 & 25.1 & 160 & 317.3 \\
\hline 390 & 7.3 & 1400 & 304 & 68.3 & 36.8 & 23.5 & 69 & 31.2 & 305 & 329.5 \\
\hline 391 & 7.4 & 700 & 172 & 7.3 & 23.6 & 3.3 & 31 & 3.96 & 105 & 345 \\
\hline 392 & 7.3 & 800 & 204 & 2.4 & 25.3 & 5.5 & 38 & 4.4 & 110 & 396.6 \\
\hline 401 & 7.24 & 689 & 108.5 & 15.8 & 15.6 & 1.1 & 8 & 3.6 & 18.5 & 373 \\
\hline 410 & 7.12 & 1120 & 147 & 23.5 & 38.4 & 4.7 & 105 & 13.7 & 31.2 & 364 \\
\hline 424 & 7.58 & 865 & 19.6 & 96.6 & 44.5 & 3.4 & 83 & 33.2 & 13.7 & 378 \\
\hline 457 & 7.29 & 1080 & 101 & 29.2 & 83.8 & 3.6 & 98 & 34.6 & 33.8 & 378 \\
\hline 458 & 7.13 & 1138 & 76.8 & 26.2 & 144 & 6.8 & 120 & 36.1 & 83.5 & 345 \\
\hline 460 & 7.4 & 410 & 74.1 & 3.65 & 6.9 & 0.8 & 17.7 & 0.1 & 4.8 & 225.7 \\
\hline
\end{tabular}




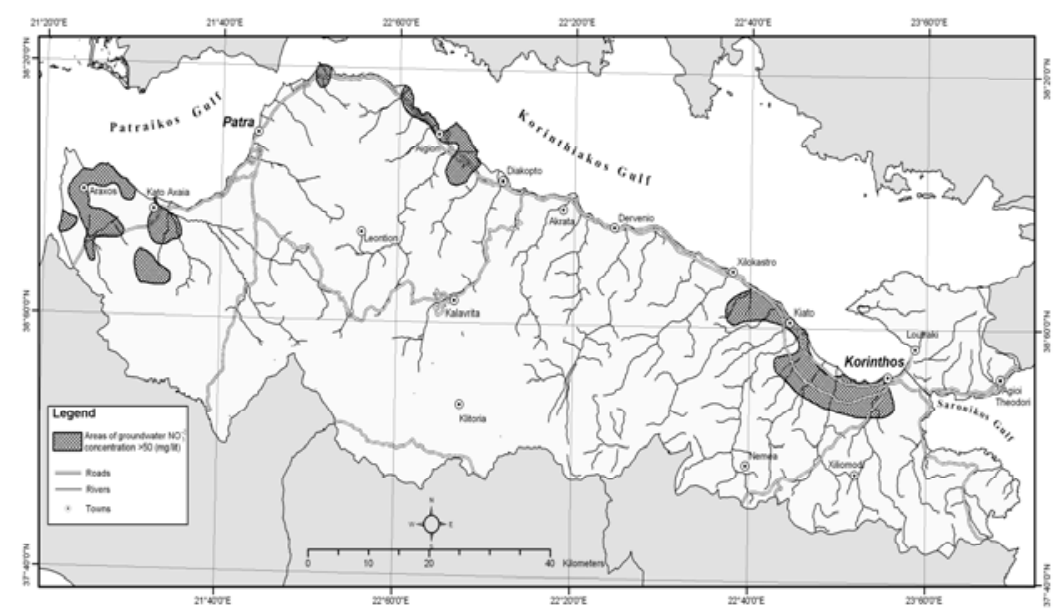

Figure 7. Areas affected by nitrate pollution $\left(\mathrm{NO}_{3}{ }^{-}\right.$concentration $\left.>50 \mathrm{mg} \mathrm{l}^{-1}\right)$

Table 6. $\mathrm{NO}_{3}{ }^{-}$and $\mathrm{Cl}^{-}$concentrations $\left(\mathrm{mg} \mathrm{l}^{-1}\right)$ of 26 selected groundwater samples in the years 1997 and 1999 (sampling location as seen in Fig. 6)

\begin{tabular}{|c|c|c|c|c|c|c|c|c|c|c|c|}
\hline No & YEAR & $\mathrm{NO}_{3}$ & $\mathrm{Cl}$ & No & YEAR & $\mathrm{NO}_{3}$ & $\mathrm{Cl}$ & No & YEAR & $\mathrm{NO}_{3}$ & $\mathrm{Cl}$ \\
\hline M1 & 1997 & 25.9 & 76 & M10 & 1997 & 7.48 & 11 & M19 & 1997 & 57.6 & 5 \\
\hline M1 & 1999 & 28 & 31 & M10 & 1999 & 7.7 & 11 & M19 & 1999 & 62 & 7 \\
\hline M2 & 1997 & 6.2 & 44 & M11 & 1997 & 19.8 & 17 & M20 & 1997 & 18.5 & 43 \\
\hline M2 & 1999 & 5.3 & 44 & M11 & 1999 & 27.2 & 25 & M20 & 1999 & 22 & 46 \\
\hline M3 & 1997 & 26.4 & 51 & M12 & 1997 & 35.2 & 81 & M21 & 1997 & 64.7 & 88 \\
\hline M3 & 1999 & 33 & 62 & M12 & 1999 & 84.5 & 91 & M21 & 1999 & 52.8 & 120 \\
\hline M4 & 1997 & 4.4 & 28 & M13 & 1997 & 27.9 & 30 & M22 & 1997 & 26.8 & \\
\hline M4 & 1999 & 2.2 & 35 & M13 & 1999 & 29 & 55 & M22 & 1999 & 33.2 & \\
\hline M5 & 1997 & 6.6 & 26 & M14 & 1997 & 14.5 & 32 & M23 & 1997 & 33 & \\
\hline M5 & 1999 & 7.1 & 23 & M14 & 1999 & 20.2 & 42 & M23 & 1999 & 41 & \\
\hline M6 & 1997 & 21.6 & 26 & M15 & 1997 & 35.2 & 29 & M24 & 1997 & 37.8 & \\
\hline M6 & 1999 & 11.4 & 41 & M15 & 1999 & 32.1 & 17 & M24 & 1999 & 45 & \\
\hline M7 & 1997 & 34.7 & 41 & M16 & 1997 & 6.6 & 20 & M25 & 1997 & 56.7 & 86 \\
\hline M7 & 1999 & 62.2 & 51 & M16 & 1999 & 4.4 & 15 & M25 & 1999 & 62 & 109 \\
\hline M8 & 1997 & 15.9 & 44 & M17 & 1997 & & 55 & M26 & 1997 & 58.5 & 30 \\
\hline M8 & 1999 & 35.6 & 22 & M17 & 1999 & & 320 & M26 & 1999 & 66 & 32 \\
\hline M9 & 1997 & 6.2 & 14 & M18 & 1997 & 104.2 & 35 & & & & \\
\hline M9 & 1999 & 7.5 & 65 & M18 & 1999 & 110 & 36 & & & & \\
\hline
\end{tabular}

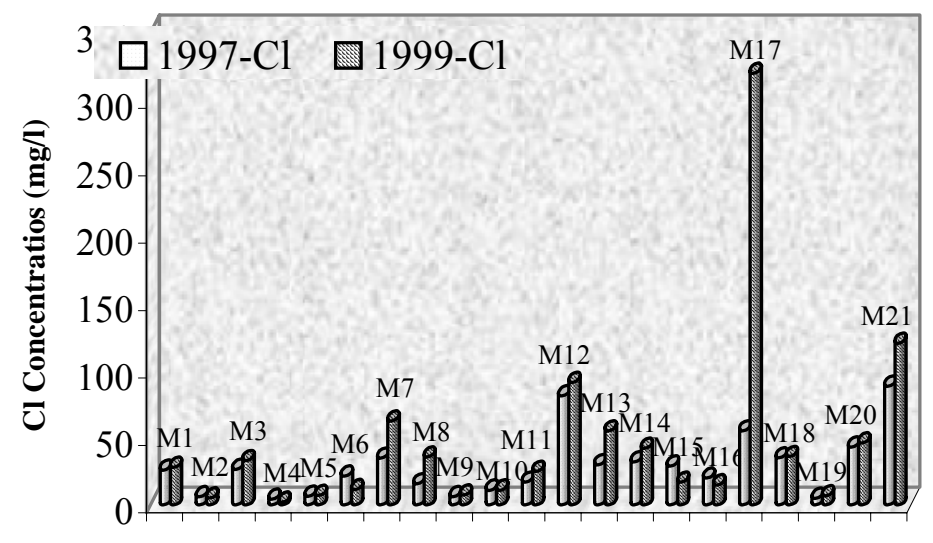

Figure 8. Chloride variation of representative samples during the years 1997 and 1999 


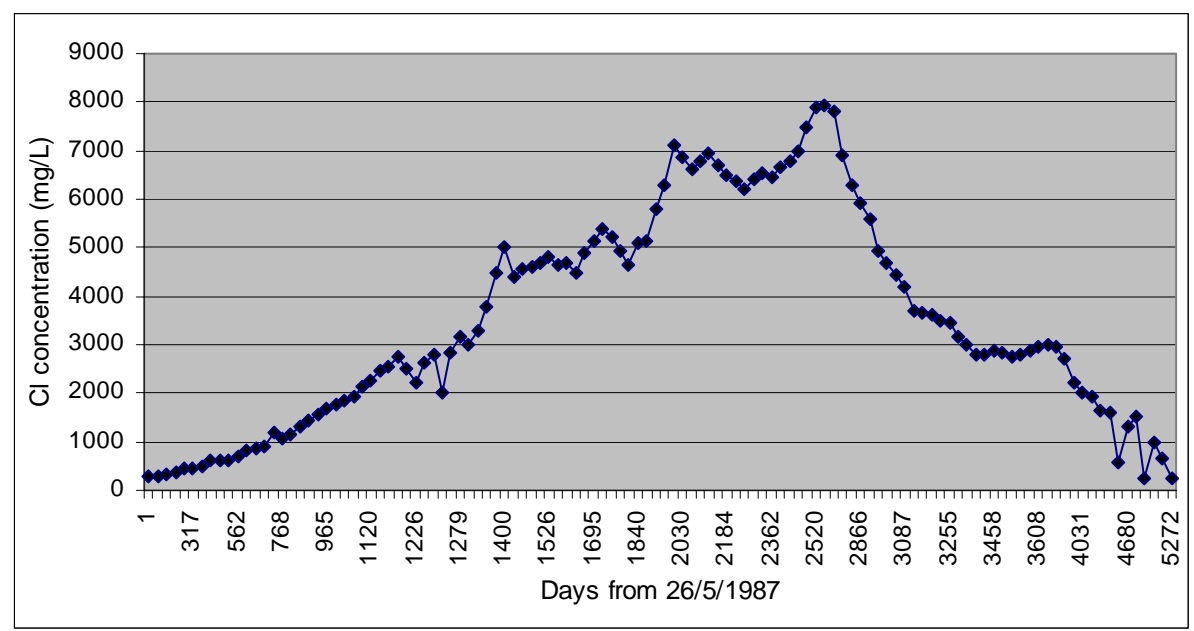

Figure 9. Chloride concentration $\left(\mathrm{mgl}^{-1}\right)$ fluctuations in groundwater from the coastal alluvial aquifer of Glafkos basin, 1987-2001

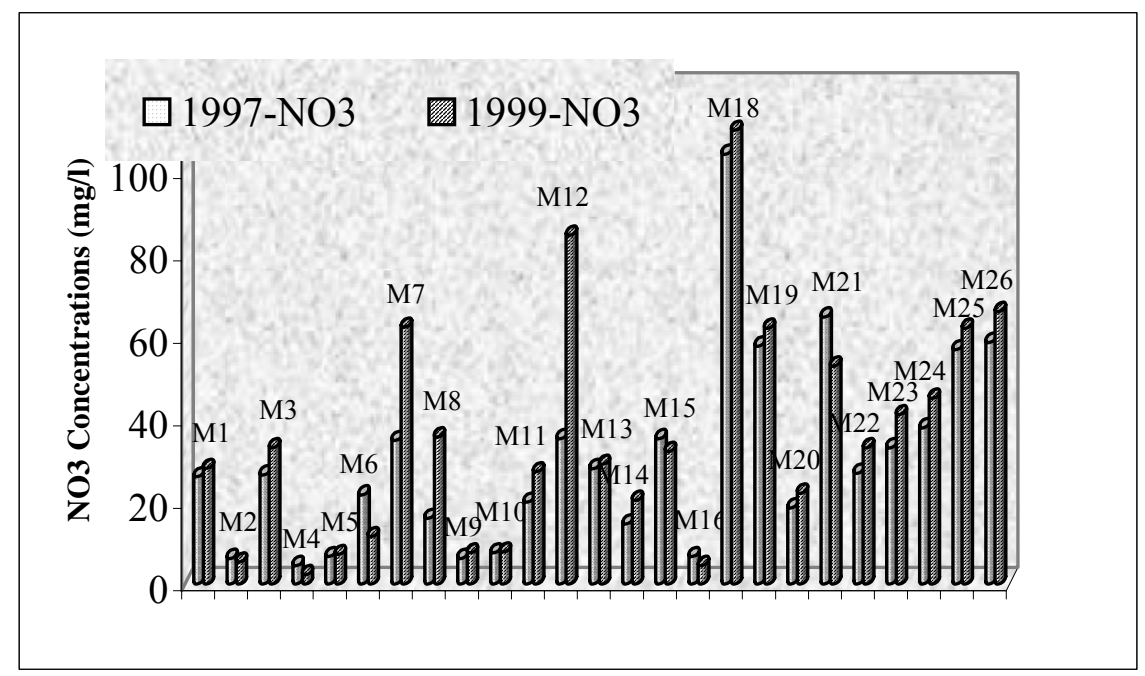

Figure 10. Nitrate variation of representative samples during the years 1997 and 1999

\section{CONCLUSIONS-PROPOSAL SOLUTIONS}

Groundwater is an important source of the water for domestic and irrigation use and it supplies at least $80 \%$ of all the needs of North Peloponnesus. The main aquifers are the alluvial, the aquifers of coarse grained Plio-Pleistocene deposits and the karst aquifers. Karst aquifer systems discharge groundwater through springs; coastal brackish water springs and inland freshwater springs.

Degradation of groundwater quality is mainly caused by: seawater intrusion and nitrate pollution. The coastal part of this area is characterized by ongoing urbanization, tourism development and intensive agriculture. As a result, in some coastal aquifer systems of the study area a negative water balance is established, triggering seawater intrusion.

Intensified fertilization has led to considerable groundwater quality deterioration, as evidenced by the increased nitrates concentration. Other sources of groundwater pollution are leaking septic tanks in urban areas. Groundwater alone cannot meet the water supply requirements in the study area and thus a need exists to supplement with surface water. The total annual surface runoff of the study area is estimated to be $0.9-1.2 \times 10^{9} \mathrm{~m}^{3}$.

An integrated management strategy should apply to develop new ways of providing an adequate water source in coastal areas. This strategy could be based on the conjunct use of (a) groundwater, (b) the abundant discharge of river/torrents (Piros, Sithas, Asopos), (c) 
the discharge of freshwater springs, and (d) the rich and high quality groundwater reserves of the mountainous region (Killini, Feneos), which are practically not exploited.

The following recommendations are proposed in order to restore the negative water balance, to provide adequate water and to improve the water quality in coastal areas of North Peloponnesus:

1. Exploitation of surface water and groundwater simultaneously. This scheme allows a maximization of water use efficiency. Construction of Asopos dam in eastern part and Parapiros dam in western part for the twin purposes of providing drinking and irrigation water. In addition, the potential hydro-energy can be developed. Construction of small interception dams in the main streams of the hilly region, aiming at retardation of wintertime torrential flows and increasing groundwater recharge from streambed infiltration. In addition, these dams improve water supplies for agriculture requirements.

2. Reduction of groundwater abstraction should be applied in coastal areas, that have affected by seawater intrusion. Utilization of the treated wastewater from plants for irrigation purposes and artificial recharge. Under this strategy groundwater abstractions for irrigation would reduce significantly.

3. The distribution systems for drinking and irrigation purposes, from which approximately $20-30 \%$ of the water is lost, should be repaired. Water-saving techniques such as spray irrigation, drip irrigation should be applied in order to decrease the groundwater quantities for agriculture.

4. The aquifer recharge application from the rivers wintertime discharge through deep boreholes or infiltration ponds could improve the groundwater regime in some aquifers. According to the results from an artificial recharge program (Koumantakis et al., 1999) in the coastal aquifer system of Korinthia it is concluded that an annual volume of $3.5 \times 10^{6} \mathrm{~m}^{3}$ originating from Asopos river could augment groundwater budget and improve the groundwater quality. Another artificial recharge test has been constructed in Patras industrial aquifer. The simulated results indicate that, aquifer recharge with $800,000 \mathrm{~m}^{3}$ water in wet period December-March via 10 deep boreholes limits the drawdown at the end of dry period, including the irrigation period when the pumping has been increased (Voudouris et al., 2002c).

5. Planning of surface water protection measures such as banning of olive oil mill and domestic effluent disposal in rivers and streams, as well as construction of proper environmentally compatible landfills.

6. For solving the problem of water shortages in coastal areas, long-distance water allocation and transfer schemes should be built from mountainous areas.

7. Protection zones should be establish for both surface and groundwater resources in important water supply regions.

Finally, future investigations of the sustainable management of water resources in the North Peloponnesus would benefit by hydrological data monitoring, isotopic analysis, water quality monitoring, land use monitoring and computer modelling to simulate the water cycle.

\section{REFERENCES}

Daskalaki, P., (2002), Contribution to chemistry and quality of groundwaters in Greece, Ph.D. Thesis. Dep. of Geology, University of Patras.

Daskalaki, P., Voudouris, K., Diamantopoulou, P., (1998), Hydrochemical study of North Peloponnesus quaternary and plio-pleistocene aquifers, Proc. Int. Con. Protection and restoration of the environment IV, Sani, Greece, Vol. I, 108-116.

E.U. Council (1998), Council directive 98/83 about water quality intended for human consumption, Official paper of the European Communities, V. L330, 32-54.

Freeze, A. and Cherry, JA. (1979), Groundwater. Pentice Hall, Englewood cliffs.

Kasimis X., Papadopoulos A, Sousounis G and Stravopodis S. (1998), Contribution to the colloquy on the development of the Prefecture of Corinth, Unpublished report (in Greek). 
Koukis, G., Nikolaou, N., Pirgiotis, L. (1996), Runoff and proposed storage works in the county of Korinthos. Proc. 2th Panellenic Conference, Geotechnical chamber of Grecce, Larisa, Vol. II, 910-924.

Koumantakis, J., Panagopoulos, A., Stavropoulos, X., and Voudouris, K. (1999), Application of aquifer artificial recharge in the coastal alluvial basin of the northern part of Korinthos Prefecture, Proc. $5^{\text {th }}$ Conf. on Hydrogeology, Nicosia, Cyprus, 65-80, (in Greek).

Lambrakis, N., Voudouris, K., Tiniakos, L., Kalergis, G. (1997), Impacts of drought and overpumping on the Quaternary aquifers of the Glafkos basin (Patras region, W. Greece). Environmental Geology, 29 (3/4) February 1977, 209-216.

Mandilaras, D., Voudouris, K., Lambrakis, N. 1999. Fluctuation in the groundwater quality of the alluvial aquifer of Glafkos basin (Achaia, Greece). Proc. $5^{\text {th }}$ Hydrogeological conference, Nicosia, Cyprus, 407-422.

Nikolaou, N., Koukis, G., Lambrakis, N. (1997), Rainfall and landslide manifestation correlation in Korinthos, Greece. Proc. Engineering Geology and Environment. Vol. 1, 919-924. Balkema.

Panagopoulos A., Voudouris, K., Koumantakis, J., and Hionidi, M. (2001), Groundwater evolution of the northern Corinthian region coastal aquifer system, as indicated by Hydrochemistry, Proc. $9^{\text {th }}$ Int. Conf. of the Geological Society of Greece, Athens, Greece, 2001.

Panagopoulos, A., Voudouris, K, Hionidi, M., Koumantakis, J. (2002), Irrational water resources management impacts on the coastal aquifer system of Korinthia. Proc. International Conference «Restoration and Protection of the Environment V», July 2002, Skiathos. Volume I, 419-426.

Skayias, St. (1978), Inventory of karstic springs of Greece. Vol. 1, Hydrological and Hydrogeol. Investigations, No 28. Institute of Geological and Mining Research.

Stamatis, G., Voudouris, K. 2003. Marine and human activity influences on the groundwater quality of southern Korinthos area (Greece). Hydrological processes, 17, 2327-2345 (2003).

Voudouris, K. (1995), Hydrogeological conditions in NW Achaia. Ph.D. Thesis. Dep. of Geology, University of Patras.

Voudouris, K, Lambrakis, N., Tiniakos, L., Kallergis, G. (1997), Contribution to the study of the water balance in the Patras area. Proc. $7^{\text {th }}$ Conference of the Hellenic Hydrotechnical Assosiation, Patras, 50-58 (in Greek).

Voudouris, K. (1999), Spatial distribution of rainfall in North Peloponnesus. Proc. 5th Conference on Hydrology, Nicosia, Cyprus, 245-254 (in Greek).

Voudouris K., Panagopoulos, A. and Daniil, D. (2000), Implications to surface water quality of Korinthos Prefecture from anthropogenic activities, Proc. Int. Conf. Protection and Restoration of the Environment V, Thassos, Greece, 2000.

Voudouris, K, Hionidi, M., Panagopoulos, A., Koumantakis, J. (2002a), Extreme climatic events in the Prefecture of Korinthos (Greece) and their impact on groundwater resources. Proc. $5^{\text {th }}$ International Conference "Water resources management in the era of transition". European Water Resources Association. Athens, 107-114.

Voudouris, K., Panagopoulos, A., Markadonis, K. (2002b), Hydrological balance and possibilities of sustainable water resources management in Stimfalia basin (prefecture of Korinthos). Proc. $6^{\text {th }}$ Pan-Hellenic Geographical Conference. Vol. II, 327-334 (in Greek).

Voudouris, K., Diamantopoulou, P., Giannatos, G., Zannis, P. (2002c), Results of groundwater recharge on the confined aquifer in Patras industrial area. Proc. $6^{\text {th }}$ Conf. on Hydrogeology, Xanthi, 47-58, (in Greek).

Voudouris, K., Nikas, K., Antonakos, A. (2004a), Study of evolution of the seawater intrusion zone in coastal aquifers. Proc. $10^{\text {th }}$ Int. Conf. of the Geological Society of Greece (in press).

Voudouris K., Panagopoulos, A., Koumantakis, J. (2004b), Nitrate pollution in the coastal aquifer system of the Korinthos Prefecture (Greece). Global Nest: The International Journal, 6(1), 31-38, 2004. 